\title{
Radioimmunodetection of Lung Cancer Using Radioactive Antibody against a Glycoprotein (GP 68) Found in Developing Mouse Brain
}

\author{
Shuji KoJIMA ${ }^{\dagger}$, Akira AWAYA*, Miki IsHido, Akiko KuboderA, \\ Kazuhiko Kubota, Yoshihide Hashimoto*, Hideo FuKui*, \\ Hisako MURAMATSU** and Takashi MuRAmatsu** \\ Research Institute for Biosciences, Science University of Tokyo \\ 2669, Yamazaki, Noda-shi 278, Japan \\ *Institute of Biological Sciences, Mitsui Pharmaceuticals Inc. \\ Togo, Mobara-shi, Chiba-Pref. 297, Japan \\ **Department of Biochemistry, Kagoshima University School of Medicine \\ Usuki-cho, Kagoshima-shi 890, Japan \\ Received August 26, 1991
}

\begin{abstract}
The in vivo localization of a polyclonal antibody (GP68 PoAb) against a glycoprotein, which was found in developing mouse brain, was studied in murine tumor model. The biodistribution of ${ }^{125} \mathrm{I}-G P 68$ PoAb 3 days postinjection into the mice bearing eight different kinds of solid tumor represented a high uptake ratio by metastatic lung cancer, mammary tumor such as MMT 060562 and adenocarcinoma 755, and melanoma B-16. In immunoscintigraphic studies, adenocarcinoma 755 and metastatic lung cancer were successfully visualized with ${ }^{131} \mathrm{I}-G P 68$ PoAb at 3 days postinjection. The strongly positive images of these tumors with ${ }^{131}$ I-GP 68 PoAb were accorded well with the data on tissue distribution of this antibody. These results suggest that GP68 PoAb may be applicable to the detection of the mammary and/or metastatic lung cancer.
\end{abstract}

Key Words: radioimmunodetection, lung cancer, breast cancer, scintigram, polyclonal antibody, murine tumor model

\section{Introduction}

Lung cancer is one of the most important causes of cancer death. Moreover, the survival time of patients with this cancer is generally very short. Althought much research has been done on lung cancer diagnosis, no reliable tool is yet available for this purpose ${ }^{1)-4}$. New approaches are therefore urgently needed to provide techniques for the diagnosis for lung cancer.

A glycoprotein with a molecular weight of

† The author to whom correspondence should be sent; Shuji KoJimA, Research Institute for Biosciences, Science University of Tokyo, 2669, Yamazaki, Noda-shi 278, Japan.
68 kilodaltons (GP 68) was found by us in the brain of mice at the 11 th day of gestation ${ }^{5}$. Subsequently, we have found that this glycoprotein is also present in various human tumor tissues, such as lung tumor, ovarian tumor, testicular tumor, et al., and it may be a new tumor-associated antigen (unpublished data).

Our previous studies using polyclonal antibody against GP 68 (GP 68 PoAb) suggested that this protein was distinct from other tumor associated antigen, such as $\alpha$-fetoprotein (AFP), carcinoembryonic antigen (CEA), etc., and that adenocarcinoma 755, a murine mammary tumor, could be clearly visualized with ${ }^{67} \mathrm{Ga}$-DFO-GP $68 \mathrm{PoAb}^{6}$. 
In this study, we have examined the feasibility of radioimmunodetection of other kinds of tumors, particularily of lung cancer with radiolabelled GP 68 PoAb.

\section{Materials and Methods}

2.1 Preparation of GP 68 and immunization Preparation of GP 68 and immunization were done as previously reported ${ }^{6}$.

\subsection{Radioiodination of GP $68 \mathrm{PoAb}$}

For the tissue distribution studies, the GP $68 \mathrm{PoAb}$ was labelled with ${ }^{125} \mathrm{I}-\mathrm{NaI}$ by the chloramine-T methods using limiting amounts of chloramine- $\mathrm{T}^{7}$. The antibody was also labelled with ${ }^{131} \mathrm{I}-\mathrm{NaI}$ in the same manner for radioimmunoscintigraphy. The specific activities were about $7.4 \mathrm{MBq} / \mathrm{mg}$ for ${ }^{125} \mathrm{I}-\mathrm{GP} 68$ $\mathrm{PoAb}$, and $740 \mathrm{MBq} / \mathrm{mg}$ for ${ }^{131} \mathrm{I}-\mathrm{GP} 68 \mathrm{PoAb}$.

\subsection{Animal tumor model and biodistribu- tion}

Male C57BL/6 mice, weighing about $25 \mathrm{~g}$, were housed in an SPF facility and used 5-6 weeks of age. The animals were inoculated SC with adenocarcinoma 755-, Lewis lung carcinoma 3LL-, MMT060562-, Colon 38-, or melanoma B-16-tumor tissues through an interscapular incision into the right flank. Ehrlich tumor and sarcoma-180 (S-180) cells suspended in sterilized phosphate-buffered saline (PBS) were SC transplanted into the male ddY mice. Seven days after inoculation the tumor-bearing mice were IV injected via the tail vein with ${ }^{125} \mathrm{I}-\mathrm{GP} 68$ PoAb $(37 \mathrm{kBq}$, $5 \mu \mathrm{g}$ of antibody as protein/animal). They were killed at 3 days postinjection, and the organs were removed, weighed and counted for ${ }^{125} \mathrm{I}$ radioactivity with a $\gamma$-counter (Aloka ARC 301). Blood specimens were withdrawn from the abdominal aorta. The biodistribution data are presented as a percentage of the injected total radioactivity per gram of tissue ( $\%$ ID $/ g$ tissue). The metastatic lung cancer was produced by an IV injection of
Lewis lung carcinoma $3 \mathrm{LL}$ cells $\left(1 \times 10^{5}\right)$ suspended in sterilized PBS into male C57BL/6 mice. The animals were used for this experiment at around 3 weeks after the injection.

\section{$2 \cdot 4$ Imaging study}

For imaging studies, tumor bearing mice were IV injected into the tail veins with 3.7 $\mathrm{MBq}(5 \mu \mathrm{g})$ of ${ }^{131} \mathrm{I}-\mathrm{GP} 68$ PoAb. Then the animals were anesthetized with sodium pentobarbital at suitable intervals. Images were obtained with a scintillation camera equipped with a high-energy parallel hole collimator (Ohio Nuclear $\Sigma 400$ series). The camera was set to $364 \mathrm{keV}$ for ${ }^{131} \mathrm{I}$, and a total of 50000 counts was accumulated for each image. Images were made at 1,3 , and 5 days postinjection. No sodium iodine was injected to inhibit thyroid uptake of free radioactive iodine through the experiments.

2.5 Histological evaluation of the metastatic lung cancer

The metastatic lung cancer tissues were fixed in a $4 \%$ paraformaldehyde solution buffered with $0.1 \mathrm{M}$ phosphate buffer, $\mathrm{pH} 7.4$. Tissue sections were cut after routine processing from paraffin blocks and stained with hematoxylin-eosin (H-E). Normal lung tissues were used as a negative control.

\section{Results}

The tissue distributions of the ${ }^{125}$ I-labeled GP $68 \mathrm{PoAb}$ at 3 days after the injection into various tumor-bearing mice are represented in Table 1 . The uptake ratio ( $\% \mathrm{ID} / \mathrm{g}$ tissue) of GP $68 \mathrm{PoAb}$ by the tumor was high in the murine mammary tumor (MMT 060562) and the metastatic lung cancer, with 9.56 and 8.61 , respectively. A moderate uptake ratio was observed in adenocarcinoma 755 , melanoma B-16, Lewis $3 \mathrm{LL}$, and colon 38. While, there are no specific localization of this antibody in Ehrlich tumor and S-180. Tumor to blood $(\mathrm{T} / \mathrm{B})$, tumor to liver $(\mathrm{T} / \mathrm{L})$, and 
Table 1 Biodistribution of ${ }^{125} \mathrm{I}-\mathrm{GP} 68 \mathrm{PoAb}$ in murine solid tumor-bearing mice at 3 days after the IV injection

$(\% \text { injected dose } / \mathrm{g} \text { tissue })^{*}$

\begin{tabular}{|c|c|c|c|c|}
\hline Tissue & Sarcoma-180 & Ehrlich & Lew is $3 \mathrm{LL}$ & Colon 38 \\
\hline Blood & $3.84 \pm 0.68$ & $4.01 \pm 0.23$ & $10.48 \pm 1.07$ & $9.13 \pm 1.25$ \\
\hline Liver & $0.99 \pm 0.16$ & $1.00 \pm 0.07$ & $1.99 \pm 0.28$ & $1.53 \pm 0.14$ \\
\hline Kidneys & $1.45 \pm 0.14$ & $1.49 \pm 0.13$ & $4.01 \pm 0.51$ & $3.31 \pm 0.46$ \\
\hline Spleen & $0.89 \pm 0.08$ & $1.48 \pm 0.37$ & $4.15 \pm 0.66$ & $2.22 \pm 0.46$ \\
\hline Heart & $0.84 \pm 0.05$ & $1.20 \pm 0.25$ & $2.25 \pm 0.39$ & $1.90 \pm 0.26$ \\
\hline Lungs & $1.52 \pm 0.36$ & $1.33 \pm 0.25$ & $3.81 \pm 0.53$ & $2.91 \pm 0.30$ \\
\hline Pancreas & $0.43 \pm 0.09$ & $0.46 \pm 0.06$ & $1.06 \pm 0.18$ & $0.87 \pm 0.15$ \\
\hline Muscle & $0.59 \pm 0.08$ & $0.44 \pm 0.03$ & $0.64 \pm 0.11$ & $0.66 \pm 0.17$ \\
\hline Tumor & $1.83 \pm 0.32$ & $2.3 \overline{5} \pm 0.28$ & $3.65 \pm 0.77$ & $3.46 \pm 0.78$ \\
\hline $\mathrm{T} / \mathrm{B}$-ratio & $0.48 \pm 0.12$ & $0.59 \pm 0.08$ & $0.34 \pm 0.08$ & $0.42 \pm 0.11$ \\
\hline $\mathrm{T} / \mathrm{L}$-ratio & $1.85 \pm 0.44$ & $2.27 \pm 0.31$ & $1.84 \pm 0.47$ & $2.27 \pm 0.55$ \\
\hline $\mathrm{T} / \mathrm{M}$-ratio & $3.10 \pm 0.69$ & $5.39 \pm 0.77$ & $5.67 \pm 1.51$ & $5.28 \pm 1.78$ \\
\hline Tissue & $\mathrm{ADC} 7 \overline{5}$ & MMT 060562 & Melanoma B-16 & MSLC \\
\hline Blood & $8.46 \pm 0.55$ & $13.26 \pm 0.84$ & $14.24 \pm 0.07$ & $6.90 \pm 0.52$ \\
\hline Liver & $1.50 \pm 0.17$ & $2.51 \pm 0.18$ & $2.35 \pm 0.33$ & $1.30 \pm 0.12$ \\
\hline Kidneys & $3.35 \pm 0.36$ & $4.64 \pm 0.30$ & $5.21 \pm 0.44$ & $3.24 \pm 0.14$ \\
\hline Spleen & $2.30 \pm 0.40$ & $4.03 \pm 0.30$ & $4.27 \pm 0.52$ & $2.21 \pm 0.44$ \\
\hline Heart & $1.90 \pm 0.31$ & $3.24 \pm 0.20$ & $3.18 \pm 0.41$ & $1.89 \pm 0.15$ \\
\hline Lung & $2.66 \pm 0.21$ & $4.18 \pm 0.31$ & $.4 .74 \pm 0.67$ & $3.48 \pm 0.23$ \\
\hline Pancreas & $0.76 \pm 0.05$ & $1.26 \pm 0.06$ & $1.32 \pm 0.28$ & $0.90 \pm 0.11$ \\
\hline Muscle & $0.56 \pm 0.07$ & $0.94 \pm 0.06$ & $0.97 \pm 0.10$ & $0.78 \pm 0.06$ \\
\hline Tumor & $5.42 \pm 0.26$ & $9.56 \pm 0.43$ & $5.50 \pm 1.21$ & $8.61 \pm 0.92$ \\
\hline $\mathrm{T} / \mathrm{B}$-ratio & $0.64 \pm 0.06$ & $0.72 \pm 0.06$ & $0.39 \pm 0.09$ & $1.25 \pm 0.16$ \\
\hline $\mathrm{T} / \mathrm{L}$-ratio & $3.61 \pm 0.12$ & $3.81 \pm 0.32$ & $2.34 \pm 0.61$ & $6.62 \pm 1.17$ \\
\hline T/M-ratio & $9.68 \pm 0.13$ & $10.17 \pm 0.79$ & $5.67 \pm 1.38$ & $11.04 \pm 1.45$ \\
\hline
\end{tabular}

Abbreviations: Lewis 3LL, Lewis lung carcinoma 3LL; ADC, Adenocarcinoma 755; MMT 060562, Murine mammary tumor 060562; MSLC, Metastatic lung cancer.

* Each value represents the mean $\pm \mathrm{SD}$ for five animals

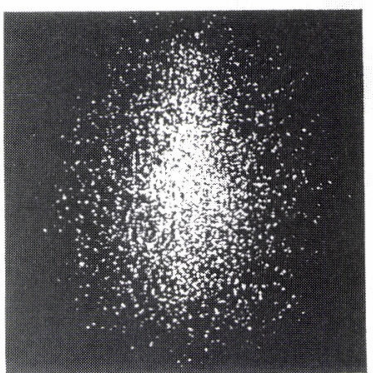

Day 1

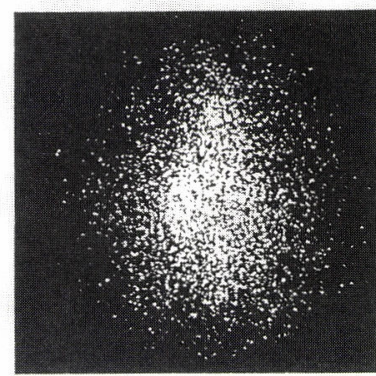

Day 3

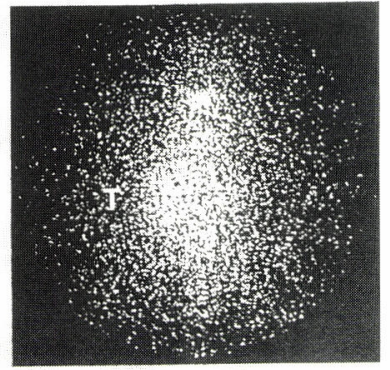

Day 5

Fig. 1 Posterior scintigram of a mouse implanted SC into the right flank with Lewis lung carcinoma $3 \mathrm{LL}$.

Images were obtained at day 1 , day 3 , and day 5 after injection of ${ }^{131} \mathrm{I}-\mathrm{GP} 68 \mathrm{PoAb}$. The position of the tumor (T) is indicated. 


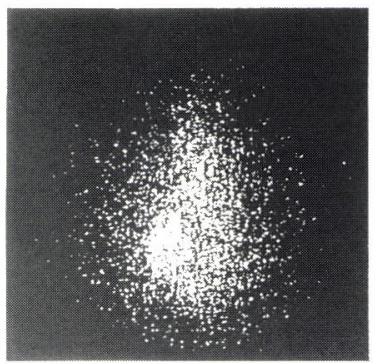

Day 1

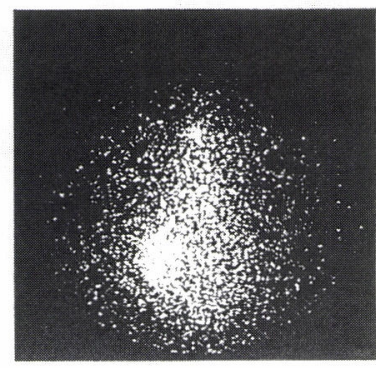

Day 3

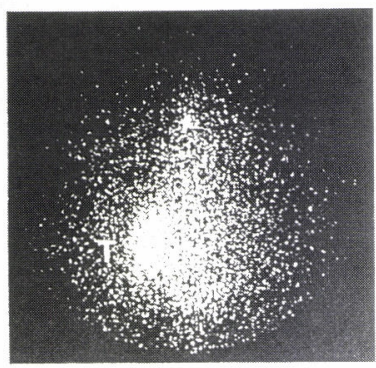

Day 5

Fig. 2 Posterior scintigram of a mouse implanted SC into the right flank with adenocarcinoma 755 .

Images were obtained at day 1 , day 3 , and day 5 after injection of ${ }^{131} \mathrm{I}-\mathrm{GP} 68 \mathrm{PoAb}$. The position of the tumor (T) is indicated.

(A) Normal mouse

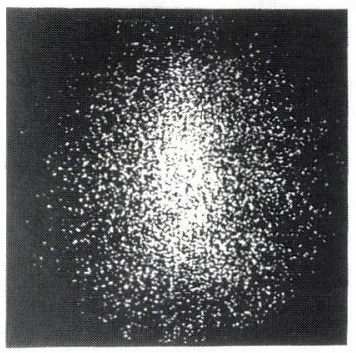

Day 1

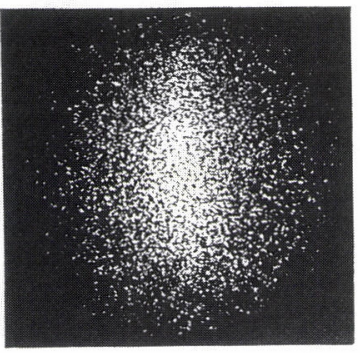

Day 3

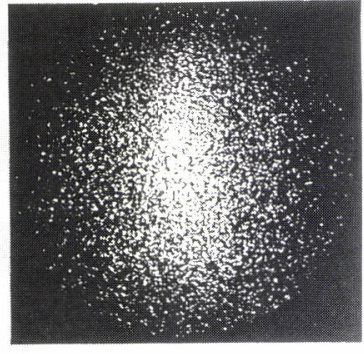

Day 5

(B) Metastatic lung cancer-bearing mouse

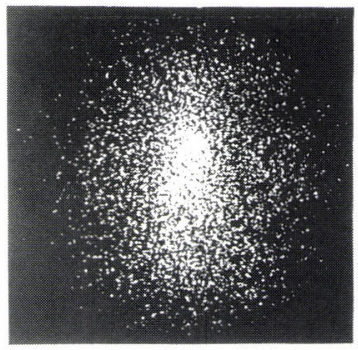

Day 1

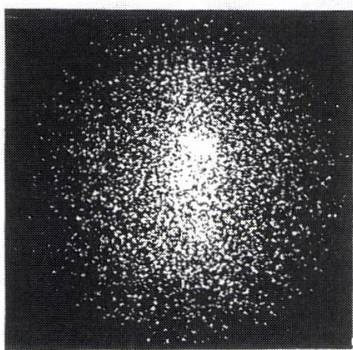

Day 3

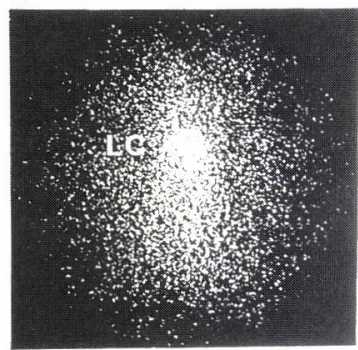

Day 5

Fig. 3 Posterior scintigrams of normal (A) and metastatic lung cancer-bearing (B) mice obtained with ${ }^{131} \mathrm{I}$-GP 68 PoAb at day 1 , day 3 , and day 5 postinjection. The position of the lung cancer (LC) is indicated.

tumor to muscle $(\mathrm{T} / \mathrm{M})$ ratios of the metastatic lung cancer were the most excellent in all cases, being $1.25 \pm 0.16,6.62 \pm 1.17$, and $11.04 \pm 1.45$, respectively.

Figures 1 and 2 show scintigraphies of Lewis lung carcinoma $3 \mathrm{LL}$ - and adenocarci- noma 755-bearing mice with ${ }^{131} \mathrm{I}-\mathrm{GP} 68 \mathrm{PoAb}$. Lewis lung carcinoma $3 \mathrm{LL}$ could not be satisfactorily descriminated from other organs. Scintigraphy of adenocarcinoma 755 was also performed as positive tumor image. This tumor was clearly delineated with ${ }^{131}$ I-GP 68 
(A) Normal mouse

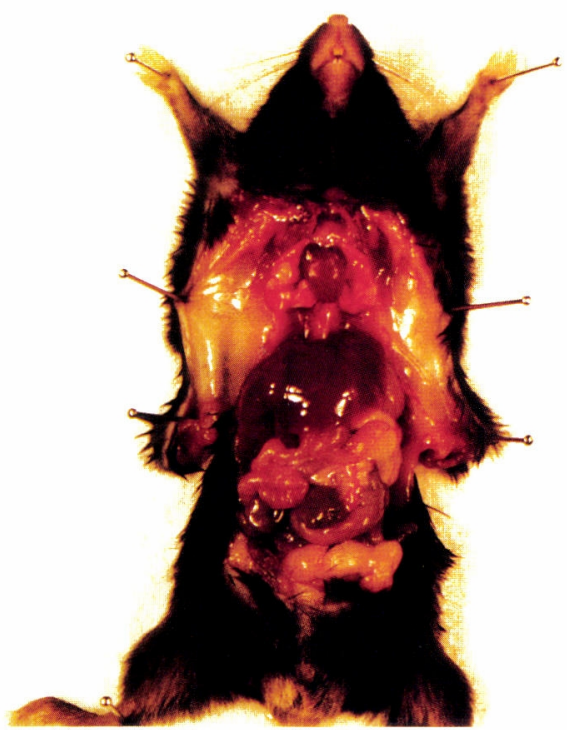

(B) Metastatic lung cancer-bearing mouse

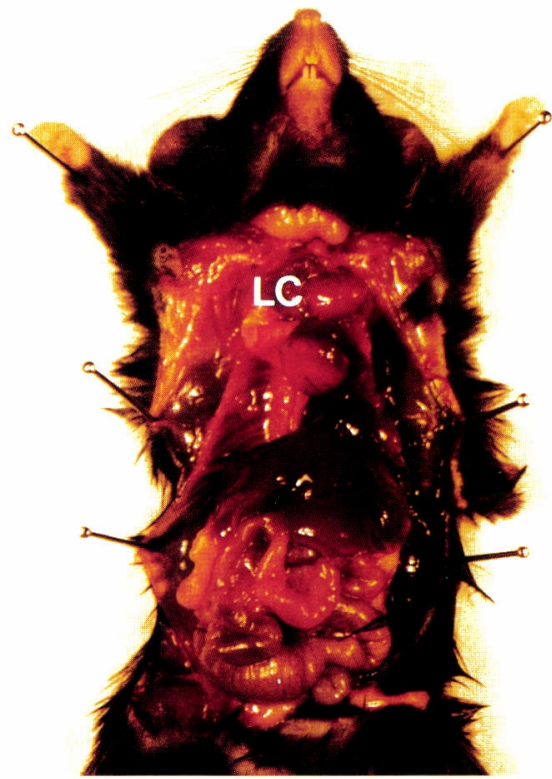

Fig. 4 Photographs of normal lung and the metastatic lung cancer. The position of the lung cancer (LC) is indicated.

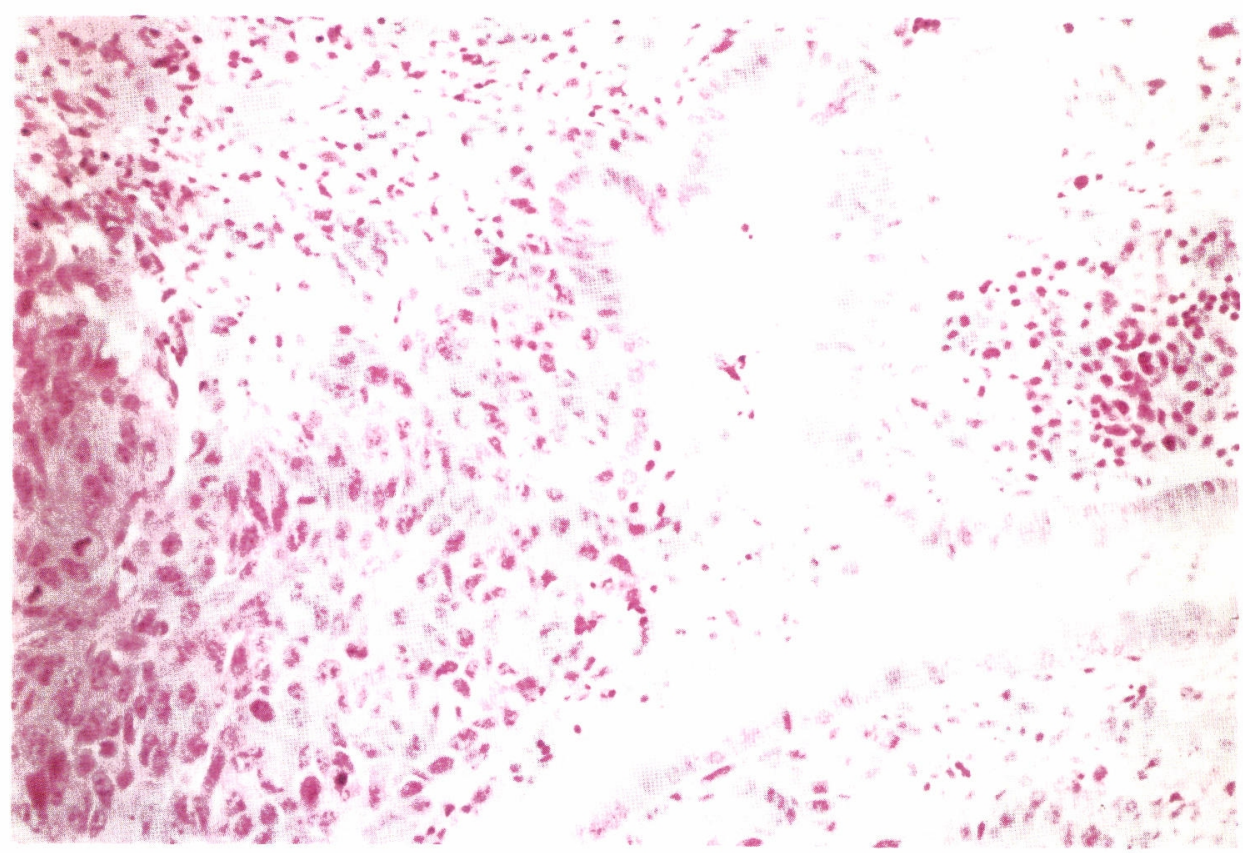

Fig. 5 Metastatic lung cancer induced by IV injection of Lewis lung carcinoma 3LL cells. $\mathrm{H}-\mathrm{E} \times 200$. 
PoAb at each time interval examined, i. e., 1,3 , and 5 days postinjection. Scintigrams of normal- and the metastatic lung cancer-bearing mice with ${ }^{131} \mathrm{I}-\mathrm{GP} 68 \mathrm{PoAb}$ at 1,3 , and 5 days postinjection are presented in Fig. 3 . The metastatic lung cancer became increasingly distinct with time as the background radioactivity decreased, as shown in Fig. 3 (B). The strongly positive area coincided well with the metastatic lung cancer observed in photographs, as shown in Fig. 4. In addition, histological evaluation was performed. As shown in Fig. 5, the metastatic tumor tissues were observed around bronchia.

\section{Discussion}

Although extensive efforts are being made to detect lung cancer and to achieve selective tumor cell killing, progress to date has been limited ${ }^{1)-4)}$.

GP 68 had been found in the embryonic brain at the 11th day of gestation, and may be a new tumor-associated marker besides CEA, AFP., etc. In our previous report, we raised the possibility of appling antibody against this glycoprotein (GP 68 PoAb) for the in vivo radioimmunodetection of cancer. Namely, a murine mammary tumor, such as adenocarcinoma 755 was shown to be clearly imaged with ${ }^{67} \mathrm{Ga}-\mathrm{DFO}-\mathrm{GP} 68$ PoAb. As shown in Table 1 , this antibody was taken up by normal lung tissue to a moderate extent. Almost all of the murine tumors investigated in our preliminary experiments also took up this antibody to the same extent as did the lung. In this work, we examined the feasibility of in vivo radioimmunodetection of the lung cancer by using radiolabelled GP 68 PoAb. As we had hoped, the lung cancer induced by a single IV injection of Lewis lung carcinoma $3 \mathrm{LL}$ cells was successfully visualized with ${ }^{131} \mathrm{I}-\mathrm{GP} 68$ PoAb (Fig. 3). On the other hand, Lewis lung carcinoma 3LL implanted into the flank could not be clearly imaged (Fig. 1). This is persumably because GP 68 PoAb is taken up by the main organs, i.e., kidneys, spleens, and lung, besides tumor tissues as shown in Table 1. In the case of adenocarcinoma 755 , this antibody is preferentially taken up by the tumor in comparison with the main organs. Despite the poor result in Lewis lung carcinomabearing mice which were implanted into the flank, GP 68 PoAb was significantly concentrated into tumor tissue after IV injection of Lewis lung carcinoma $3 \mathrm{LL}$ cells, giving excellent tumor to non-tumor tissue ratios (Table 1), which provided clear images of the metastatic lung cancer.

In conclusion, the metastatic lung cancer was successfully visualized with the radiolabelled GP 68 PoAb in this study. However, additional experiments with human tumor models are needed in order to evaluate the general utility of this radioimmunoimaging agent.

\section{Acknowledgements}

The authors thank Dr. M. Iigo, National Cancer Center, for gifts of tumor-bearing mice. Thanks are also due to Associate Prof. A. Matsuzawa, Institute of Medical Sciences, University of Tokyo, for a gift of tumorbearing mice, and for his valuable suggestions.

\section{References}

1) Chan, S.Y.T., Evan, G.I., Ritson, A., Watson, J., Wraight, P. and Sikora, K.: Brit. J. Cancer, 54, 761-769 (1986)

2) Kennel, S.J., Hotchkiss, J.A., Rorvik, M.C., Allison, D.P. and Foote, L.J.: Exp. Mol. Pathol., 47, 110-124 (1987)

3) Endo, K., Kamma, H. and Ogata, T.: $J$. Natl. Cancer Inst., 80, 835-842 (1988)

4) Kennel, S.J., Lee, R., Bultman, S. and Kabalka, G.: Nucl. Med. Biol., 17, 193200 (1990)

5) Noguchi, S., Ogata, S., Sato, M. and Muramatsu, T.: J. Biochem. (Tokyo), 96, 
881-886 (1984)

6) Kojima, S., Awaya, A., Ishido, M., Koyama, Y., Kubodera, A., Hashimoto, Y., Fukui, H., Muramatsu, H. and Muramatsu, T.: J. Cancer Res. Clin. Oncol.,
116, 851-855 (1990)

7) Sakahara, H., Endo, K., Nakashima, T., Ohta, H., Torizuka, K., Okada, K., Yoshida, O. and Hirai, H.: Kaku Igaku, 21, 805-813 (1984)

要 旨

\title{
マウス胎児脳由来糖蛋白質(GP 68)に対する抗体を用いた 肺癌の放射免疫学的検出
}

\author{
小島周二, 栗屋 昭*, 石堂美樹, 久保寺昭子, 久保田和彦, \\ 橋本吉秀*, 福井英雄*, 村松寿子**, 村松 喬** \\ 東京理科大学生命科学研究所, 278 千葉県野田市山崎 2669 \\ *三井製薬生物科学研究所, 297 千葉県茂原市東郷 1900-1 \\ **鹿児島大学医学部生化学教室, 890 鹿児島市宇宿町 1208-1
}

マウス胎児脳由来糖蛋白質（GP 68）に対するポリクローナル抗体 (GP $68 \mathrm{PoAb})$ の生体内動態を マウス腫瘍モデルで検討した。 8 種の異なる担癌マウスでの生体内動態を, ${ }^{125} \mathrm{I}-\mathrm{GP} 68 \mathrm{PoAb}$ 静脈内 投与 3 日後で比較すると, 転移性肺癌 MMT 060562 あるいは adenocarcinoma 755 等の乳癌, およ び melanoma B-16に本抗体のきわめて高い取込みが見られた。

${ }^{131} \mathrm{I}-\mathrm{GP} 68 \mathrm{PoAb}$ によるイムノシンチグラフィに打いては, 転移性肺癌および adenocarcinoma 755 が鮮明に描写され，本抗体の生体内分布の結果と良く一致した。

これらの結果より, 本抗体の肺癌および乳癌の放射免疫学的診断薬への応用が示唆された。 